\title{
A study on effects of organizational learning on organizational innovation: A case study of insurance industry
}

\author{
Maryam Marvasti ${ }^{a^{*}}$, Neda Nafari ${ }^{\mathrm{b}}$ and Ali Kavousi ${ }^{\mathrm{b}}$
}

${ }^{a}$ Masters of Business Administration, North Tehran Branch, Islamic Azad University, Tehran, Iran

${ }^{b}$ Assistant Professor, Department of Management and Accounting, North Tehran Branch, Islamic Azad University, Tehran, Iran

\section{CHRON I C LE A B T T A C T}

\section{Article history:}

Received October 28, 2013

Received in revised format

25 November 2013

Accepted 19 January 2014

Available online

January 212014

Keywords:

Organizational learning

Organizational innovation

Insurance industry

\begin{abstract}
This paper presents an empirical investigation to study the relationship between organization learning and organization innovation in one of Iranian insurance firm. The proposed study selects a sample of 300 employees who work for different positions for the case study of this paper and using Pearson correlation as well as Freedman tests determines the relationship and ranks different components of the survey. The results of this implementation have indicated that organization innovation influences on organizational learning, data distribution, interpretation and memory significantly but the effect of organizational innovation on data collection cannot be confirmed when the level of significance is five or even ten percent. The implementation of Freedman test has also indicated that Information interpretation is number priority followed by information learning, organizational distribution and organizational memory.
\end{abstract}

\section{Introduction}

Organizational commitment is a continuous process, which can be appeared by participating people to make organizational decisions and concentrating to organizational people and their success \& welfare (Grant, 1996). There are various studies on how to build an innovative organization and how organizational learning could influence on organizational innovation. Bui and Baruch (2010) developed a conceptual framework to study antecedents and outcomes of Senge's five disciplines, and presented moderators to describe the prospect associations, employing a multi-level analysis to explore various issues, from the individual level through the collective level up to the organizational level (Yli-Renko et al., 2001; Weerawardena et al., 2006).

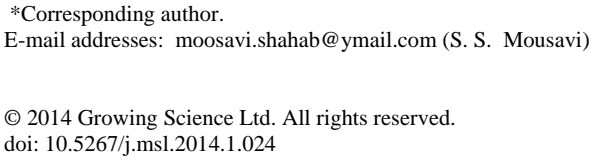


Based on this theoretical framework, they offered a set of propositions in the shape of a causal model, which creates some relationship among the constructs of the model together. They manifested wide areas of relevance to the learning organization and pointed out substantial interdependences and interactions among the different constructs associated with Senge's five disciplines of the learning organization.

Camisón and Villar-López (2011) investigated the role of organizational memory and learning capabilities as antecedents to non-technical innovation, comprising organizational and marketing innovation. They reported that both organizational memory and learning capabilities could favor the development of organizational innovation and marketing innovation. In addition, their study indicated that both kinds of non-technical innovation could promote the achievement of sustained competitive advantage.

García-Morales et al. (2007, 2012) analyzed the effects of personal mastery on organizational performance, through the dynamic capabilities of organizational learning and innovation. They confirmed these effects empirically in both large firms and SMEs and reported that personal mastery affected organizational performance directly and indirectly through organizational learning and innovation. In addition, they reported organizational learning affects organizational performance positively, both directly and indirectly through organizational innovation.

Aragón-Correa et al. (2012) proposed that leadership style and organizational learning simultaneously and positively influence firm innovation. In their survey, organizational learning had a stronger direct effect on innovation than CEO transformational leadership. However, leadership had a strong, significant impact on organizational learning, indirectly influencing firm innovation.

Gold et al. (2001) investigated the issue of effective knowledge management from the perspective of organizational capabilities and recommended that a knowledge infrastructure consisting of technology, structure, and culture along with knowledge process architecture of acquisition, conversion, application, and protection were essential organizational capabilities or "preconditions" for effective knowledge management.

Liao et al. (2008) built the constructs of knowledge inertia and examined the relationships between knowledge inertia, organizational learning and organizational innovation. They reported that knowledge inertia comprised both learning inertia and experience inertia. Jiménez-Jiménez and SanzValle (2011) reported that organizational learning and innovation contribute positively to business performance, and that organizational learning influences innovation. According to Liao and Wu (2010) organizational learning could be considered as the mediating variable between knowledge management and organizational innovation.

Sarin and McDermott (2003) investigated how leadership characteristics in new product development teams influence the learning, knowledge application, and subsequently the performance of these teams. They explained that team learning had a strong positive impact on the innovativeness and speed to market of the new products. Scarbrough (2003) concentrated on the emergence and implementation of knowledge management and its particular application in Ebank. Wang and Ahmed (2004) investigated the development and validation of the organizational innovativeness construct based on confirmatory factor analysis.

This paper presents an empirical investigation to learn the relationship between organizational learning and organization innovation. The organization of this paper first presents details of proposed study and hypotheses in section 2 while section 3 presents details of our findings and concluding remarks are given in the last to summarize the contribution of the paper. 


\section{The proposed study}

The proposed study of this paper considers the following five hypotheses,

1. There is a meaningful relationship between organizational learning and organizational innovation.

2. There is a meaningful relationship between organizational learning and organizational data collection.

3. There is a meaningful relationship between organizational learning and organizational distribution.

4. There is a meaningful relationship between organizational learning and organizational interpretation.

5. There is a meaningful relationship between organizational learning and organizational memory.

The proposed study has been accomplished among employees of insurance firm who were working in Iran. Therefore we could use the following formula to calculate the minimum number of sample size,

$n=\frac{N \times z_{\alpha / 2}^{2} \times p \times q}{\varepsilon^{2} \times(N-1)+z_{\alpha / 2}^{2} \times p \times q}$,

where $N$ is the population size, $p=1-q$ represents the yes/no categories, $z_{\alpha / 2}$ is CDF of normal distribution and finally $\varepsilon$ is the error term. Since we have $p=0.5, z_{\alpha / 2}=1.96$ and $N=1357$, the number of sample size is calculated as $n=255$. We have distributed 300 questionnaires among the participants in our survey.

The proposed study of this paper has been accomplished among some employees of insurance firm in Iran who were enrolled in various positions in this insurance firm.

There are 21 questions associated with organizational learning and 14 questions are associated with organizational innovation and all questions were designed in Likert scale. We have performed normality test using Kolmogorov-Smirnov test where the null hypothesis states that all data are normally distributed and the alternative hypothesis states that data are not normally distributed. Table 1 shows the results of our findings.

\section{Table 1}

The results of Kolmogorov-Smirnov test

\begin{tabular}{cccccccccccccc}
\hline & $\begin{array}{c}\text { Strategic } \\
\text { innovation }\end{array}$ & $\begin{array}{c}\text { Innovative } \\
\text { behavior }\end{array}$ & $\begin{array}{c}\text { Innovation } \\
\text { in process }\end{array}$ & $\begin{array}{c}\text { Innovation } \\
\text { in services }\end{array}$ & $\begin{array}{c}\text { Organizational } \\
\text { innovation }\end{array}$ & $\begin{array}{c}\text { Organizational } \\
\text { memory }\end{array}$ & $\begin{array}{c}\text { Interpretation } \\
\text { Distribution }\end{array}$ & $\begin{array}{c}\text { Data } \\
\text { collection }\end{array}$ & $\begin{array}{c}\text { Organizational } \\
\text { learning }\end{array}$ \\
\hline Number & 300 & 300 & 300 & 300 & 300 & 300 & 300 & 300 & 300 & 300 \\
$\begin{array}{c}\text { Kolmogorov- } \\
\text { Smirnov Z } \\
\text { Sig. }\end{array}$ & -2.11 & 3.542 & 2.109 & -1.398 & 1.111 & 2.211 & 1.243 & -2.243 & 2.487 \\
\hline
\end{tabular}

Therefore, we use Spearman correlation test to examine different hypotheses. Table 2 summarizes the results of some basic statistics associated with our survey. As we can observe from the results of 
Table 1, all components of the survey including strategic innovation, innovation behavior, innovation in process, etc. are normally distributed.

Table 2

The summary of some basic statistics

\begin{tabular}{cc|c|c|c|c|c|c|c|c|c|}
\hline Mean & 10.69 & 13.88 & 16.88 & 12.88 & 38.48 & 14.42 & 12.56 & 18.06 & 17.44 & 52.50 \\
\hline Standard deviation & 3.90 & 4.78 & 5.85 & 5.35 & 7.03 & 5.42 & 3.90 & 5.11 & 6.58 & 15.40 \\
\hline Median & 5 & 5 & 6 & 6 & 22 & 12 & 12 & 15 & 12 & 36 \\
Mode & 6 & 7 & 6 & 8 & 11 & 6 & 5 & 4 & 6 & 15 \\
Max & 6 & 5 & 21 & 28 & 43 & 85 & 18 & 16 & 14 & 44 \\
Min & 16 & 18 & 5 & 5 & 9 & 20 & 2 & 6 & 3 & 12 \\
\hline
\end{tabular}

\section{The results}

In this section, we present details of our findings on testing various hypotheses of the survey based on the implementation of Pearson correlation test. Table 3 demonstrates the summary of our findings.

Table 3

The summary of Pearson correlation test

\begin{tabular}{llcl}
\hline Hypothesis & Number & Correlation & Sig. \\
\hline Organizational innovation and learning & 300 & 0.701 & 0.00 \\
Organizational innovation and data collection & 300 & 0.52 & 0.73 \\
Organizational innovation and data distribution & 300 & 0.60 & 0.00 \\
Organizational innovation and interpretation & 300 & 0.47 & 0.00 \\
Organizational innovation and memory & 300 & 0.77 & 0.00 \\
\hline
\end{tabular}

As we can observe from the results of Table 3, organizational innovation influences on organizational learning, data distribution, interpretation and memory significantly but the effect of organizational innovation on data collection cannot be confirmed when the level of significance is five or even ten percent. We have also applied Freedman test to rank the relative importance of each components and Table 4 demonstrates the summary of our findings.

\section{Table 4}

The summary of the results of Freedman test on the effects of organizational learning on organizational innovation

\begin{tabular}{lccrrc}
\hline Variable & Mean rank & Sum of rank & Average & Error & Priority \\
\hline Organizational memory & 2.33 & 270.00 & 3.11 & 0.68 & Third \\
Information learning & 2.57 & 298.50 & 3.27 & 0.87 & Second \\
Information distribution & 1.94 & 224.50 & 3.05 & 0.69 & Fourth \\
Information interpretation & 3.16 & 367.00 & 3.53 & 0.53 & First \\
\hline
\end{tabular}

As we can observe from the results of Table 4, information interpretation is number one priority followed by information learning, organizational distribution and organizational memory. We have also performed Freedman test on details of organizational innovation itself and Table 5 shows details of our findings.

\section{Table 5}

The summary of the results of Freedman test on the effects of components of organizational innovation

\begin{tabular}{lrrrrc}
\hline Variable & Mean rank & Sum of rank & Average & Error & Priority \\
\hline Innovation on products & 3.25 & 377.00 & 3.68 & 0.47 & First \\
Strategic innovation & 2.53 & 293.00 & 3.27 & 0.63 & Second \\
Innovation in behavior & 2.34 & 271.00 & 3.32 & 0.59 & Third \\
Innovation in process & 1.89 & 219.00 & 3.12 & 0.56 & Fourth \\
\hline
\end{tabular}


The results of Table 5 indicate that innovation on products and services is the most important item followed by strategic innovation, innovation in behavior and process.

\section{Conclusion}

We have presented an empirical investigation to study the effects of organizational learning on organization innovation. The proposed study has been performed among some employees who worked for an insurance firm in Iran. The results of this implementation have indicated that organization innovation influenced on organizational learning, data distribution, interpretation and memory significantly but the effect of organizational innovation on data collection could not be confirmed when the level of significance was five or even ten percent. The implementation of Freedman test has also indicated that Information interpretation was number one priority followed by information learning, organizational distribution and organizational memory. The results of this survey are consistent with findings reported earlier by Camisón and Villar-López (2011), GarcíaMorales et al. (2007) and Wang and Ahmed (2004).

\section{References}

Aragón-Correa, J. A., García-Morales, V. J., \& Cordón-Pozo, E. (2007). Leadership and organizational learning's role on innovation and performance: lessons from Spain. Industrial marketing management, 36(3), 349-359.

Bui, H., \& Baruch, Y. (2010). Creating learning organizations: a systems perspective. Learning Organization, The, 17(3), 208-227.

Camisón, C., \& Villar-López, A. (2011). Non-technical innovation: organizational memory and learning capabilities as antecedent factors with effects on sustained competitive advantage. Industrial Marketing Management, 40(8), 1294-1304.

García-Morales, V. J., Lloréns-Montes, F. J., \& Verdú-Jover, A. J. (2007). Influence of personal mastery on organizational performance through organizational learning and innovation in large firms and SMEs. Technovation,27(9), 547-568.

García-Morales, V. J., Jiménez-Barrionuevo, M. M., \& Gutiérrez-Gutiérrez, L. (2012). Transformational leadership influence on organizational performance through organizational learning and innovation. Journal of Business Research, 65(7), 1040-1050.

Gold, A. H., Malhotra, A., \& Segars, A. H. (2001). Knowledge management: an organizational capabilities perspective. J. of Management Information Systems,18(1), 185-214.

Grant, R. M. (1996). Toward a knowledge-based theory of the firm. Strategic management journal, 17, 109-122.

Jiménez-Jiménez, D., \& Sanz-Valle, R. (2011). Innovation, organizational learning, and performance. Journal of Business Research, 64(4), 408-417.

Liao, S. H., Fei, W. C., \& Liu, C. T. (2008). Relationships between knowledge inertia, organizational learning and organization innovation. Technovation, 28(4), 183-195.

Liao, S. H., \& Wu, C. C. (2010). System perspective of knowledge management, organizational learning, and organizational innovation. Expert Systems with Applications, 37(2), 1096-1103.

Sarin, S., \& McDermott, C. (2003). The effect of team leader characteristics on learning, knowledge application, and performance of cross-functional new product development teams. Decision Sciences, 34(4), 707-739.

Scarbrough, H. (2003). Knowledge management, HRM and the innovation process. International Journal of Manpower, 24(5), 501-516.

Wang, C. L., \& Ahmed, P. K. (2004). The development and validation of the organisational innovativeness construct using confirmatory factor analysis. European Journal of Innovation Management, 7(4), 303-313. 
Weerawardena, J., O'Cass, A., \& Julian, C. (2006). Does industry matter? Examining the role of industry structure and organizational learning in innovation and brand performance. Journal of Business Research, 59(1), 37-45.

Yli-Renko, H., Autio, E., \& Sapienza, H. J. (2001). Social capital, knowledge acquisition, and knowledge exploitation in young technology-based firms. Strategic management journal, 22(6-7), 587-613. 